\title{
Autoimmunity in chronic liver disease caused by hepatitis delta virus
}

\author{
DANIELA ZAULI, CRISTINA CRESPI, FB BIANCHI, A CRAXI,* E PISI \\ From the Istituto di Patologia Medica I, University of Bologna, Italy, and the *Istituto di Medicina Generale $e$ \\ Pneumologia (Clinica Medica), University of Palermo, Italy
}

SUMMARY Recent evidence shows that chronic liver disease induced by hepatitis delta virus is closely associated with production of autoantibodies. To verify this sera from patients with hepatitis delta virus and from those with hepatitis B virus mediated chronic liver disease were tested for a panel of autoantibodies.

Although the traditional non-organ specific autoantibodies were similarly distributed in the two groups, a considerably higher prevalence of IgG basal cell layer antibodies, IgM anti-intermediate filaments, and IgG antimicrotubule antibodies was found.

Although these phenomena might be secondary to hepatitis delta virus infection, they might be the serological markers of underlying immune events.

Although it was initially suggested that hepatitis delta virus is directly cytopathic and that the liver injury in hepatitis delta virus infection is not immunologically mediated, ${ }^{1}$ some recent evidence suggests that chronic liver disease associated with hepatitis delta virus is characterised by a higher production of autoantibodies $^{2}$ than occurs in chronic liver disease induced by hepatitis B virus. In about half the cases we studied we found basal cell antibodies, and in $13 \%$ of these cases Crivelli et al described a new antimicrosomal antibody reacting mainly with human substrates. ${ }^{34}$ The traditional non-organ specific autoantibodies characterising the autoimmune subset of chronic liver disease are, on the contrary, rarely found in both hepatitis $B$ virus and chronic liver disease induced by hepatitis delta virus. ${ }^{45}$

Antibodies shown by immunofluorescence to react with the three major components of the cytoskeleton (microfilaments, intermediate filaments, and microtubules) have recently been recognised in various diseases, ${ }^{6-8}$ including autoimmune and hepatitis $B$ virus mediated chronic liver disease. ${ }^{910}$ The antimicrofilament (actin) pattern is usually seen in autoimmune chronic liver disease, whereas the antiintermediate filament pattern mainly occurs in hepatitis B virus mediated chronic liver disease. ${ }^{9}$ The reports on cases of hepatitis B virus showed that associated hepatitis delta virus infection had not been studied.

To verify whether the increased cytoskeleton antibody production in cases of hepatitis B virus might be Accepted for publication 5 March 1986 related to hepatitis B virus associated hepatitis delta virus infection we tested sera from patients with chronic liver disease positive and negative for hepatitis delta virus for a panel of autoantibodies, including cytoskeleton antibodies, using a new method developed in our laboratory. ${ }^{11}$

\section{Patients and methods}

Sera from 55 patients with chronic liver disease induced by hepatitis delta virus aged 8 to 62 years (median 37 years) and 43 patients with chronic liver disease induced by hepatitis B virus aged 3 to 66 years (median 35 years) were studied. Table 1 shows the diagnosis of chronic liver disease based on clinical, biochemical, and histological data. In all cases intrahepatic hepatitis delta virus was tested by an indirect immunofluorescence method, and in 52 cases serum antihepatitis delta virus was determined by radioimmunoassay. ${ }^{3}$ Serum hepatitis B virus markers were measured by commercial radioimmunoassay (Abbott Laboratories, Chicago, USA). Thirty blood donors were tested as controls.

\section{IMMUNOFLUORESCENCE STUDIES}

An indirect immunofluorescence method was used on the following substrates: rat forestomach, stomach, liver, and kidney for basal cell antibodies and nonorgan specific autoantibodies; peripheral blood mononuclear cells treated with vinblastine for cytoskeleton antibodies. ${ }^{311}$ Sera were tested at $1 / 40$ for basal cell antibodies and other antibodies and at 1/10 
Table 1 Clinical, biochemical, and histological data of healthy controls and patients with chronic liver disease induced by hepatitis delta virus and hepatitis $B$ virus

\begin{tabular}{|c|c|c|c|c|c|c|c|c|}
\hline \multirow[t]{2}{*}{ Cases } & \multirow[t]{2}{*}{ No } & \multicolumn{2}{|c|}{ Sex } & \multirow{2}{*}{$\begin{array}{l}\text { Age (range) } \\
\text { (years) }\end{array}$} & \multirow[t]{2}{*}{$\mathrm{CPH}$} & \multirow[t]{2}{*}{$C A H$} & \multirow[t]{2}{*}{ Cirrhosis } & \multirow[t]{2}{*}{$\mathrm{HBeAg} /$ anti-HBe } \\
\hline & & $M$ & $F$ & & & & & \\
\hline $\begin{array}{l}\text { Hepatitis delta virus } \\
\text { Hepatitis B virus } \\
\text { Healthy controls }\end{array}$ & $\begin{array}{l}55 \\
43 \\
30\end{array}$ & $\begin{array}{l}36 \\
37 \\
24\end{array}$ & $\begin{array}{r}19 \\
6 \\
6\end{array}$ & $\begin{array}{l}37(8-62) \\
35(3-66) \\
40(34-56)\end{array}$ & $\begin{array}{l}2 \\
0 \\
0\end{array}$ & $\begin{array}{r}18 \\
18 \\
0\end{array}$ & $\begin{array}{r}35 \\
25 \\
0\end{array}$ & $\begin{array}{c}12 / 42 \\
20 / 22 \\
0\end{array}$ \\
\hline
\end{tabular}

$\overline{\mathrm{CPH}}=$ chronic persistent hepatitis; $\mathrm{CAH}=$ chronic active hepatitis.

Table 2 Prevalence of cytoskeleton, ${ }^{*}$ and basal cell antibodies in chronic liver disease induced by hepatitis delta virus and hepatitis $B$ virus (figures in parentheses are numbers \%)

\begin{tabular}{|c|c|c|c|c|c|c|}
\hline & No & $\begin{array}{l}\text { Cytoskeleton } \\
\text { antibodies }\end{array}$ & Antimicrofilaments & $\begin{array}{l}\text { Anti-intermediate } \\
\text { microfilaments }\end{array}$ & Antimicrotubules & $\begin{array}{l}\text { Basal cell } \\
\text { antibodies }\end{array}$ \\
\hline $\begin{array}{l}\text { Hepatitis delta virus } \\
\text { Hepatitis B virus } \\
\text { Controls }\end{array}$ & $\begin{array}{l}55 \\
43 \\
30\end{array}$ & $\begin{array}{c}43(78) \dagger \\
17(39) \\
0\end{array}$ & $\begin{array}{l}3(5) \\
0 \\
0\end{array}$ & $\begin{array}{l}39(71) \ddagger \\
17(39) \\
0\end{array}$ & $\begin{array}{l}24(44)^{* *} \\
4(9) \\
0\end{array}$ & $\begin{array}{l}33(60) \S \\
1(2) \\
0\end{array}$ \\
\hline
\end{tabular}

Hepatitis delta virus $v$ hepatitis B virus; $\nmid p=0.0002 ; \ddagger p=0.003 ; * * p=0.0004 ; \S p<0.0001$

*Antimicrofilaments, anti-intermediate filaments, antimicrotubules.

dilution for cytoskeleton antibodies. Immunoglobulin classes of the antibodies were assessed using fluorescein isothiocynate conjugated monospecific antihuman IgG, IgA, and IgM.

STATISTICAL ANALYSIS

Statistical analysis was performed using the $\chi^{2}$ test, with Yates's correction, and by the Wilcoxon rank sum test.

\section{Results}

Table 2 shows the prevalence of cytoskeleton antibodies and basal cell antibodies. The overall prevalence of cytoskeleton antibodies was significantly higher in chronic liver disease induced by hepatitis delta virus than in chronic liver disease induced by hepatitis B virus $(p=0.0002)$. Antiintermediate filaments and antimicrotubule antibodies accounted for the significance $(p=0.003$ and 0.0004 , respectively). Antimicrofilament antibodies were found in only three cases of chronic liver disease induced by hepatitis delta virus and in none of the hepatitis B virus group. As to non-organ specific autoantibodies, the overall prevalence was similar in the two groups: $37 \%$ in hepatitis delta virus and $29 \%$ in hepatitis B virus. The most common antibody was smooth muscle (22\% and $19 \%)$ followed by the antinuclear antibody $(9 \%$ and $16 \%)$. Basal cell antibodies were present in most of the cases of hepatitis delta virus $(60 \%)$, whereas it was found in only one patient with hepatitis B virus $(2 \%, \mathrm{p}<0.0001)$. Basal cell antibodies and cytoskeleton antibodies were present together in 22 cases of chronic liver disease induced by hepatitis delta virus (40\%) but not in any of the cases of hepatitis B virus. Thus basal cell antibodies or cytoskeleton antibodies, or both, were present in 54 cases of hepatitis delta virus ( $98 \%)$ and in 18 cases of chronic liver disease induced by hepatitis delta virus $(42 \%)(\mathrm{p}<0.0001)$.

In both groups intermediate filament antibodies were mainly of the IgM class (55 of 56) and antimicrotubule antibodies were of the IgG class ( 27 of 28). The three antimicrofilament antibodies found in cases of hepatitis delta virus were all of the IgM class. Basal cell antibodies were prevalent in the IgG class (33 of 34), but reactivities in the IgA and IgM classes were also found in seven and five cases, respectively.

The age and sex distribution were the same in subjects with positive and negative antibodies, except for the finding of both basal cell antibodies and cytoskeleton antibodies; this was more common in women $(61 \%)$ than in men $(30 \%)$. The difference, however, was not significant $(p=0.06)$. In cases of hepatitis $B$ virus antibodies were similarly distributed between $\mathrm{HBeAg}$ and anti-HBe positive subjects: $40 \%$ and $39 \%$, respectively.

\section{Discussion}

Our findings indicate that chronic liver disease associated with hepatitis delta virus is characterised by a higher production of autoantibody than that found in hepatitis B virus mediated chronic liver disease. In fact, cytoskeleton antibodies and basal cell antibodies were detected in nearly all the cases examined $(98 \%)$. As to cytoskeleton antibodies, the most common 
pattern proved to be IgM anti-intermediate filaments. This association has been reported in about 12 of 32 HBsAg positive cases of chronic liver disease by Pedersen et al. ${ }^{9}$ The prevalence of hepatitis delta virus infection in those cases, however, had not been analysed, and the results, therefore, are not comparable with ours.

IgM antibodies to microtubules have been reported previously in infectious mononucleosis ${ }^{12}$ and IgG antibodies to microtubules in $50 \%$ of sera from patients with alcoholic liver disease, ${ }^{10}$ but not in hepatitis B virus or chronic liver disease induced by hepatitis delta virus. The prevalence of the antimicrofilaments pattern in cases of hepatitis delta virus, in contrast, was low. A similar prevalence has been reported by Pedersen et al in their HBsAg positive cases. This is to be expected, as it has been well documented that the antiactin microfilaments reactivity is almost exclusive of smooth muscle antibody positive autoimmune subsets of chronic liver disease, including primary biliary cirrhosis. ${ }^{91013}$ In our cases all three microfilament antibodies were IgM, whereas antiactin microfilament antibodies in autoimmune chronic liver disease are usually IgG.

In conclusion, there seem to be three subsets of chronic liver disease associated with hepatitis delta virus as far as autoantibodies are concerned: one characterised by basal cell antibodies only $(20 \%)$; one by cytoskeleton antibodies (38\%); and one by both types of antibody (40\%), which is a common finding in women. It should be emphasised in this context that basal cell antibodies specificities seem to differ from those of cytoskeleton antibodies. Firstly, the combination of the two is present in only $40 \%$ of cases, and the immunoglobulin classes differ (intermediate filaments antibodies being IgM and basal cell antibodies predominantly IgG). Moreover, we have shown that some basal cell antibodies might be directed against structures of epithelial cells containing keratin ${ }^{14}$ and that the intermediate filaments of mononuclear cells do not contain keratin but vimentin, ${ }^{11}$ like other mesenchymal cells.

As to the importance of these phenomena in chronic hepatitis delta virus infection, they might be secondary events emerging from the denaturation or rearrangement of cytoskeletal structures induced by viral infection. It has, in fact, been shown that viruses can cause important reorganisation of both actin microfilaments and microtubules. ${ }^{1516}$ Lenkei et $\mathrm{al}^{17}$ have shown that basal cell antibodies can react with thymic stellate epithelial cells, which are thought to participate in thymic hormone production. Although probably not with a primary role in the genesis of liver injury, these antibodies might still have a role in hepatitis delta virus infection by interfering with normal cytoskeletal structures. These components, although mainly intracellular, can be expressed on the cellular membrane. ${ }^{18} 19$

\section{References}

${ }^{1}$ Thomas HC, Pignatelli M, Scully LJ. Viruses and immune reactions in the liver. Scand J Gastroenterol 1985;20 (suppl):105-17.

${ }^{2}$ Rizzetto M, Verme G. Delta hepatitis. Present status. J Hepatol 1985;1:187-93.

${ }^{3}$ Zauli D, Fusconi M, Crespi C, Bianchi FB, Craxì A, Pisi E. Close association between basal cell layer antibodies and hepatitis B virus-associated chronic delta infection. Heptatology 1984;4: 1103-6.

${ }^{4}$ Crivelli O, Lavarini C, Chiaberge E, et al. Microsomal autoantibodies in chronic infection with $\mathrm{HBsAg}$-associated delta agent. Clin Exp Immunol 1983;54:232-8.

${ }^{5}$ Mackay IR. Immunological aspects of chronic active hepatitis. Hepatology 1983;3:724-8.

${ }^{6}$ Zauli D, Crespi C, Dall'Amore P, Bianchi FB, Pisi E. Antibodies to the cytoskeleton components and other autoantibodies in inflammatory bowel disease. Digestion 1985;32:140-4.

${ }^{7}$ Zauli D, Crespi C, Mancini AF, Zerbini M, Bianchi FE, Pisi E. Relationship between smooth muscle and cytoskeleton antibodies in neuroblastoma. Tumori 1985;71:425-30.

${ }^{8}$ Zauli D, Crespi C, Miserocchi F, Zerbini M, Bianchi FB, Pisi E. Relationship between smooth muscle and cytoskeleton antibodies in human sera. La Ricerca in Clinica e Laboratorio 1985; 15:133-8.

${ }^{9}$ Pedersen JS, Toh BH, Mackay IR, et al. Segregation of autoantibodies to cytoskeletal filaments, actin and intermediate filaments, with two types of chronic active hepatitis. Clin Exp Immunol 1982;48:527-32.

${ }^{10}$ Kurki P, Miettinen A, Salaspuro M, Virtanen I, Stenman S. Cytoskeleton antibodies in chronic active hepatitis, primary biliary cirrhosis and alcoholic liver disease. Hepatology 1983;3:297-302.

${ }^{11}$ Zauli D, Crespi C, Bianchi FB, Pisi E. Immunofluorescent detection of anti-cytoskeleton antibodies using vinblastinetreated mononuclear cells. J Immunol Methods 1985;82:77-82.

12 Mead GM, Cowin P, Whitehouse JMA. Anti-tubulin antibody in healthy adults and patients with infectious mononucleosis and its relationship to smooth muscle antibody (SMA). Clin Exp Immunol 1980;39:328-36.

${ }^{13}$ Cunningham AL, Mackay IR, Frazer IH, et al. Antibody to $G$-actin in different categories of alcoholic liver disease: quantification by an ELISA and significance for alcoholic cirrhosis. Clin Immunol Immunopathol 1985;34:158-64.

${ }^{14}$ Zauli D, Crespi C, Miserocchi F, Bianchi FB, Pisi E. Heterogeneity of basal call layer antibody (BCLA) associated with chronic delta infection. J Hepatol 1985;2:S3522-00.

${ }^{15}$ Lösse D, Lauer R, Weber D, Radsar K. Actin distribution and synthesis in human fibroblasts infected by cytomegalovirus. Arch Virol 1982;71:353-9.

${ }^{16}$ Hegg U, Haase W, Brauer D, Falke D. Microtubules and microfilaments in HSV-infected rabbit-kidney cells. Arch Virol 1981;70:233-46.

${ }^{17}$ Lenkei R, Biberfeld G, Magnius O, Fagraeus A, Biberfeld P. Autoantibodies to the basal cells of squamous epithelium react with thymic epithelial cells. Clin Immunol Immunopathol 1985;34:11-9.

${ }^{18}$ Dulbecco R, Unger M, Bologna M, Battifora H, Syka P, Okada S. Cross-reactivity between Thy-1 and component of intermediate filaments demonstrated using a monoclonal antibody. Nature 1981;292:772-4.

${ }^{19}$ Dales S, Fujinami RS, Oldstone MBA. Serologic relatedness between Thy-1.2 and actin revealed by monoclonal antibody. $J$ Immunol 1983;131:1332-8.

Requests for reprints to: Professor D Zauli, Istituto di Patologia Medica I, Policlinico S Orsola, Via Massarenti 9, I-40138 Bologna, Italy. 